DUONG TRAN DinH ${ }^{1,2}$, HANNA PIEKARSKA-BONIECKA ${ }^{1}$, MARTA RZAŃSKA-WIECZOREK ${ }^{1,3}$

${ }^{1}$ Department of Entomology and Environmental Protection

Poznań University of Life Sciences, Poland

${ }^{2}$ Institute of Ecology and Biological Resources

Vietnam Academy of Science and Technology, Vietnam

${ }^{3}$ Department of Biological Pest Control

Institute of Plant Protection - National Research Institute, Poland

\title{
APHIDIINAE (HYMENOPTERA, BRACONIDAE) OCCURRING IN AGRICULTURAL ENVIRONMENTS, FORESTS AND URBAN AREAS IN POLAND
}

\author{
APHIDIINAE (HYMENOPTERA, BRACONIDAE) \\ WYSTĘPUJĄCE W ŚRODOWISKU ROLNICZYM I LEŚNYM \\ ORAZ W ZIELENI MIEJSKIEJ NA TERENIE POLSKI
}

\begin{abstract}
The authors of the article used literature data to present the species diversity of the Aphidiinae (Braconidae) subfamily in agricultural crops, forests and urban green space in Poland. In total, 83 species of parasitoids were found in all the environments. Aphidiinae preferred forests most: 61 species of the parasitoids were found there. The agricultural and urban environments did not attract so many Aphidiinae parasitoid species as forests. There were 41 species found in the agricultural environment and 38 species in the urban green space. All the environments were infested by the following 15 species: Aphidius ervi, A. matricariae, A. picipes, A. salicis, A. setiger, A. sonchi, Diaeretiella rapae, Ephedrus persicae, E. plagiator, Lysiphlebus ambiguous, L. fabarum, Praon abjectum, $P$. volucre, Trioxys acalephae and $T$. angelicae.
\end{abstract}

Key words: Aphidiinae, parasitoid, agricultural environment and forest, urban areas

\section{Introduction}

Parasitic Hymenoptera are one of the factors limiting the number of aphids. They parasitise both larval instars and adult aphids. They mainly belong to the Aphidiinae 
Tran Dinh, D., Piekarska-Boniecka, H., Rzańska-Wieczorek, M. (2017). Aphidiinae (Hymenoptera, Braconidae) occurring in agricultural environments, forests and urban areas in Poland. Nauka Przyr. Technol., 11, 3, $305-313$. http://dx.doi.org/10.17306/J.NPT.00197

Haliday subfamily (Hymenoptera: Braconidae), which includes about 615 species worldwide (Yu et al., 2012). According to the Fauna Europea database, 213 species were recorded in Europe until 2013 (Fauna Europaea..., n.d.). During the European studies there were about 109 species found in Germany (Belokobylskij et al., 2003), 145 species in the Czech Republic (Starý, 2006), 37 species in Bulgaria (Atanassova, 1997) and 32 species in Belgium (Lopes et al., 2016).

Although aphid parasites are characterised by good crop protection potential, they have not been studied thoroughly in Poland, especially in terms of species diversity in different environments.

The aim of the study was to demonstrate the current state of knowledge about aphidiid parasitoids occurring in different environments in Poland, such as: the agricultural environment, forests and urban green space. The study was based on reference publications.

\section{Results}

Hymenoptera Aphidiinae is a small wasp that specialises in parasitising aphids. Aphidiines mummify the host and undergo pupation inside the dead host mummy. Until now several studies have been conducted in Poland. 83 species of the Aphidiinae subfamily have been recorded in the agricultural environment, forests and urban areas in Poland. Kierych (1975) was one of the first authors to identify 41 species of the Aphidiinae subfamily in all these environments in Poland.

\section{Agricultural environments}

There were studies on the occurrence of Aphidiinae in different environments. Nowadays the agricultural environment in Poland is a mosaic of diverse habitats, consisting of arable land, semi-natural habitats, human infrastructures and occasional natural environments. In total 41 species of Aphidiinae were recorded in agricultural environments (Barczak, 1988; Barczak et al., 2005, 2014; Krawczyk et al., 2006; Pankanin-Franczyk, 1982; Wiąckowski, 1997). There were differences in the number of species collected in different regions. To be specific, 29 species were found in Bydgoszcz, 18 species in Kielce, 7 species in Opole, 9 species both in Warsaw and Wrocław (Table 1).

\section{Forests}

Although there has not been much research on Aphidiinae parasitoids in forests, results point to a significant number of species of the Aphidiinae subfamily. 61 Aphidiinae species were identified from specimens collected in forests (Table 1). This environment was the most abundant in aphid parasites. There is great potential for discovering new species, which could be used for scientific and other purposes. The scientific accomplishments of Barczak et al. (2013), Wiąckowski and Wiąckowska (2000), and Wiąckowski et al. (2001) need to be mentioned. Wiąckowski and Wiąckowska (2000) isolated 30 species of forest Aphidiidae on 27 species of trees and shrubs. So far only one species of aphid in the forest environment, namely Tuberculoides unicornfish, underwent 
Tran Dinh, D., Piekarska-Boniecka, H., Rzańska-Wieczorek, M. (2017). Aphidiinae (Hymenoptera, Braconidae) occurring in agricultural environments, forests and urban areas in Poland. Nauka Przyr. Technol., 11, 3, $305-313$. http://dx.doi.org/10.17306/J.NPT.00197

Table 1. A list of species of the Aphidiinae subfamily occurring in agricultural environments, forests and urban areas in Poland

\begin{tabular}{|c|c|c|}
\hline Place & Species & Number \\
\hline 1 & 2 & 3 \\
\hline \multicolumn{3}{|c|}{ Agricultural environments } \\
\hline $\begin{array}{l}\text { Bydgoszcz } \\
\text { surrounding area }\end{array}$ & $\begin{array}{l}\text { Aphidius avenae (Hal.), A. ervi (Hal.), A. matricariae Hal., A. rhopalosiphi Dest., } \\
\text { A. transcaspicus Telenga, A. urticae Hal., A. uzbekistanicus Luzh., Diaeretiella } \\
\text { rapae (M'Int.), Ephedrus persicae Frog., E. palaestinensis Mack., E. plagiator } \\
\text { (Nees), Lipolexis gracilis Forst., L. scutellaris Mack., Lysephedrus validus (Hal.), } \\
\text { Lysiphlebus cardui (Marsh.), L. ambiguous (Hal.), L. dissolutus (Nees), L. faba- } \\
\text { rum (Marsh.), L. safavii Starý, L. testaceipes Cress., Monoctonus crepidis (Hal.), } \\
\text { Praon abjectum (Hal.), P. volucre (Hal.), Trioxys acalephae (Marsh.), T. angelicae } \\
\text { (Hal.), T. auctus (Hal.), T. centaureae (Hal.), T. heraclei Hal., T. indicus S.R.S. }\end{array}$ & 29 \\
\hline $\begin{array}{l}\text { Kielce surround- } \\
\text { ing area }\end{array}$ & $\begin{array}{l}\text { Aphidius aquilus Mack., A. avenae (Hal.), A. ervi (Hal.), A. megourae Starý, } \\
\text { A. picipes (Nees), A. salicis Hal., A. setiger (Mack.), A. sonchi Marsh., Diae- } \\
\text { retiella rapae (M'Int.), Ephedrus lacertosus (Hal.), E. plagiator (Nees), Lysiphle- } \\
\text { bus fabarum (Marsh.), Praon abjectum (Hal.), P. dorsale (Hal.), P. volucre (Hal.), } \\
\text { Trioxys acalephae (Marsh.), T. angelicae (Hal.), T. brevicornis Hal. }\end{array}$ & 18 \\
\hline $\begin{array}{l}\text { Opole surround- } \\
\text { ing area }\end{array}$ & $\begin{array}{l}\text { Aphidius ervi (Hal.), A. rhopalosiphi Dest., A. uzbekistanicus Luzh., Ephedrus } \\
\text { plagiator (Nees), Praon gallicum Starý, P. volucre (Hal.), Trioxys angelicae } \\
\text { (Hal.) }\end{array}$ & 7 \\
\hline $\begin{array}{l}\text { Warsaw sur- } \\
\text { rounding area }\end{array}$ & $\begin{array}{l}\text { Aphidius ervi (Hal.), A. picipes (Nees), A. rhopalosiphi Dest., A. uzbekistanicus } \\
\text { Luzh., Diaeretiella rapae (M'Int.), Ephedrus plagiator (Nees), Praon necans } \\
\text { Mack., P. volucre (Hal.), Trioxys auctus (Hal.) }\end{array}$ & 9 \\
\hline $\begin{array}{l}\text { Wrocław sur- } \\
\text { rounding area }\end{array}$ & $\begin{array}{l}\text { Aphidius ervi (Hal.), A. picipes (Nees), A. rhopalosiphi Dest., A. uzbekistanicus } \\
\text { Luzh., Diaeretiella rapae (M'Int.), Ephedrus plagiator (Nees), Praon gallicum } \\
\text { Starý, P. volucre (Hal.), Toxares deltiger (Hal.) }\end{array}$ & 9 \\
\hline Total & & 41 \\
\hline \multicolumn{3}{|c|}{ Forests } \\
\hline $\begin{array}{l}\text { Bydgoszcz } \\
\text { surrounding area }\end{array}$ & Ephedrus plagiator (Nees), Praon abjectum (Hal.), P. volucre (Hal.) & 3 \\
\hline $\begin{array}{l}\text { Kielce surround- } \\
\text { ing area }\end{array}$ & $\begin{array}{l}\text { Aphidius aquilus Mack., A. cingulatus Ruthe, A. hortensis Marsh., A. rosae Hal., } \\
\text { A. setiger (Mack.), A. sonchi Marsh., A. urticae Hal., Diaeretus leucopterus } \\
\text { (Hal.), Dyscritulus planiceps (Marsh.), Ephedrus lacertosus (Hal.), Lysiphlebus } \\
\text { ambiguous (Hal.), L. fabarum (Marsh.), L. salicaphis (Fitch.), Pauesia abietis } \\
\text { (Marsh.), P. cupressobii (Starý), P. infulata (Hal.), P. juniperorum Starý, } \\
\text { P. laricis (Hal.), P. pini (Hal.), P. unilachni (Gah.), Praon abjectum (Hal.), } \\
\text { P. bicolor Mack., P. flavinode (Hal.), P. volucre (Hal.), Trioxys acalephae } \\
\text { (Marsh.), T. angelicae (Hal.), T. cirsii (Curt.), T. falcatus Mack., T. pallidus Hal., } \\
\text { T. parauctus Starý }\end{array}$ & 30 \\
\hline
\end{tabular}


Tran Dinh, D., Piekarska-Boniecka, H., Rzańska-Wieczorek, M. (2017). Aphidiinae (Hymenoptera, Braconidae) occurring in agricultural environments, forests and urban areas in Poland. Nauka Przyr. Technol., 11, 3, $305-313$. http://dx.doi.org/10.17306/J.NPT.00197

Table 1 - cont.

\begin{tabular}{|c|c|c|}
\hline 1 & 2 & 3 \\
\hline $\begin{array}{l}\text { Central and } \\
\text { southern Poland }\end{array}$ & $\begin{array}{l}\text { Aclitus obscuripennis (Forst.), Aphidius absinthii Marsh., A. aulacorthi Starý, } \\
\text { A. aquilus Mack., A. avenae (Hal.), A. cingulatus Ruthe, A. ervi (Hal.), A. funebris } \\
\text { Mack., A. hieraciorum Starý, A. hortensis Marsh., A. lonicerae (Marsh.), } \\
\text { A. matricariae Hal., A. megourae Starý, A. pascuorum (Marsh.), A. picipes } \\
\text { (Nees), A. ribis Hal., A. rosae Hal., A. salicis Hal., A. setiger (Mack.), A. sonchi } \\
\text { Marsh., A. urticae Hal., Areopraon lepelleyi (Wat.), Diaeretiella rapae (M'Int.), } \\
\text { Dyscritulus planiceps (Marsh.), Ephedrus lacertosus (Hal.), E. minor Stelf., } \\
\text { E. persicae (Frog.), E. plagiator (Nees), Lysiphlebus ambiguous (Hal.), L. faba- } \\
\text { rum (Marsh.), L. fritzmulleri Mack., L. salicaphis (Fitch.), Monoctonus pseudo- } \\
\text { platani (Marsh.), Pauesia abietis (Marsh.), P. cupressobii (Starý), } \\
\text { P. infulata (Hal.), P. juniperorum (Starý), P. laricis (Hal.), P. pini (Hal.), } \\
\text { P. silvestris Starý, P. unilachni (Gah.), Praon abjectum (Hal.), P. absinthii } \\
\text { (Bign.), P. bicolor Mack., P. dorsale (Hal.), P. exsoletum (Nees), P. flavinode } \\
\text { (Hal.), P. pubescens Starý, P. rosaecola Starý, P. volucre (Hal.), Trioxys } \\
\text { acalephae (Marsh.), T. angelicae (Hal.), T. brevicornis Hal., T. centaureae (Hal.), } \\
\text { T. cirsii (Curt.), T. falcatus Mack., T. genistae (Mack.), T. hortorum Starý, } \\
\text { T. pallidus Hal., T. parauctus Starý }\end{array}$ & 60 \\
\hline Total & & 61 \\
\hline \multicolumn{3}{|c|}{ Urban green space } \\
\hline Bydgoszcz & $\begin{array}{l}\text { Aphidius colemani Vier., A. matricariae Hal., Diaeretiella rapae (M'Int.), Ephe- } \\
\text { drus persicae Frog., E. plagiator (Nees), Lysiphlebus cardui (Marsh.), L. fabarum } \\
\text { (Marsh.), Praon abjectum (Hal.), P. volucre (Hal.), Trioxys acalephae (Marsh.), } \\
\text { T. angelicae (Hal.) }\end{array}$ & 11 \\
\hline Kielce & $\begin{array}{l}\text { Aphidius absinthii Marsh., A. aulacorthi Starý, A. caraganae (Starý), A. ervi } \\
\text { (Hal.), A. matricariae Hal., A. pascuorum (Marsh.), A. picipes (Nees), A. ribis } \\
\text { Hal., A. rosae Hal., A. salicis Hal., A. setiger (Mack.), A. sicarius Mack., } \\
\text { A. sonchi Marsh., Diaeretiella rapae (M'Int.), Dyscritulus planiceps (Marsh.), } \\
\text { Ephedrus minor Stelf., E. lacertosus (Hal.), E. persicae Frog., E. plagiator (Nees), } \\
\text { Lysiphlebus ambiguous (Hal.), L. fabarum (Marsh.), Praon abjectum (Hal.), } \\
\text { P. bicolor Mack., P. dorsale (Hal.), P. exsoletum (Nees), P. flavinode (Hal.), } \\
\text { P. pubescens Starý, P. rosaecola Starý, P. volucre (Hal.), Trioxys angelicae (Hal.), } \\
\text { T. centaureae (Hal.), T. cirsii (Curt.), T. genistae (Mack.), T. pallidus Hal. }\end{array}$ & 34 \\
\hline Lublin & Aphidius ervi (Hal.) & 1 \\
\hline Poznań & $\begin{array}{l}\text { Ephedrus persicae Frog., E. plagiator (Nees), Monoctonus cerasi (Marsh.), Praon } \\
\text { volucre (Hal.), Trioxys angelicae (Hal.) }\end{array}$ & 5 \\
\hline Warsaw & Ephedrus plagiator (Nees), Praon volucre (Hal.), Trioxys angelicae (Hal.) & 3 \\
\hline Wrocław & Aphidius matricariae Hal., A. colemani Vier., Praon volucre (Hal.) & 3 \\
\hline Total & & 38 \\
\hline
\end{tabular}


Tran Dinh, D., Piekarska-Boniecka, H., Rzańska-Wieczorek, M. (2017). Aphidiinae (Hymenoptera, Braconidae) occurring in agricultural environments, forests and urban areas in Poland. Nauka Przyr. Technol., 11, 3, $305-313$. http://dx.doi.org/10.17306/J.NPT.00197

comprehensive development of its parasitoids (Barczak, 1994). Ephedrus plagiator and Praon volucre were the most common species in forests (Wiąckowski and Wiąckowska, 2000).

\section{Urban areas}

Urban aphid parasitoids were studied by various authors in Kielce, Bydgoszcz, Lublin, Poznań, Warsaw and Wrocław (Barczak, 1991-1992a; Barczak et al., 1999, 2005; Cierniewska, 1973; Goszczyński et al., 2000; Halarewicz-Pacan and Sobota, 1998; Jaśkiewicz, 2003; Ślusarczyk, 1994; Wiąckowski and Wiąckowska, 1996; Wiąckowski et al., 1997). There were significant differences in the number of species collected in each region: 34 species in Kielce, 11 in Bydgoszcz, 1 in Lublin, 5 in Poznań, 3 species both in Warsaw and Wrocław. In total 38 aphid parasitoids were found in urban areas. Aphidius, Ephedrus, Praon and Trioxys were the most common genera. Aphidius ervi, Ephedrus plagiator, Praon volucre, Trioxys angelicae were common species in each area under study (Barczak et al., 1999; Goszczyński et al., 2000; Halarewicz-Pacan and Sobota, 1998; Jaśkiewicz, 2003; Ślusarczyk, 1994). However, some species were less common. They were found only in some urban areas in Poland, e.g. Dyscritules planiceps in Kielce and Monoctonus cerasi in Poznań.

\section{Discussion}

Some species were very common in agro-ecosystems. Aphidius ervi, Ephedrus plagiator and Praon volucre were found in all places under study in Bydgoszcz, Kielce, Opole, Warsaw and Wrocław. Other species were observed only in two or three places, e.g. Trioxys auctus and Praon gallicum. Some species were found in one place only, e.g. Praon necans in Warsaw (Pankanin-Franczyk, 1987), Toxares deltiger in Wrocław (Pankanin-Franczyk and Sobota, 1998), Aphidius sonchi and Ephedrus lacertosus in Kielce (Wiąckowski, 1997), Lipolexis gracilis and Lysephedrus validus in Bydgoszcz (Barczak, 1991-1992b).

Differences in species compositions depended not only on the region but also on the type of plant. The Lysiplebus fabarum parasitoid species seemed to predominate in beet plantations (Barczak, 1988; Barczak et al., 2005). Aphidius uzbekistanicus was the most important parasitoid for aphid control in rye, wheat and barley (Pankanin-Franczyk, 1982; Pankanin-Franczyk and Ceryngier, 1995; Pankanin-Franczyk and Sobota, 1998). Aphidius uzbekistanicus predominated in winter crops, whereas Aphidius rhopalosiphi was the most common species in spring crops (Sobota et al., 1998). In late spring and the first half of summer maize aphids were parasitised by Hymenoptera of the Aphidiinae subfamily. Aphidius rhopalosiphi was the dominant species among Aphidiinae, while Praon volucre was subdominant (Krawczyk et al., 2006). The Diaeretiella genus was predominant in sugar beet plantations. These insects are attracted by the volatiles (isothiocyanates) of the Cruciferae (Sobota and Gabryś, 2000). Diaeretiella rapae was the most common parasitoid (Sobota et al., 1998; Twardowski and Hurej, 2000). 
Tran Dinh, D., Piekarska-Boniecka, H., Rzańska-Wieczorek, M. (2017). Aphidiinae (Hymenoptera, Braconidae) occurring in agricultural environments, forests and urban areas in Poland. Nauka Przyr. Technol., 11, 3, $305-313$. http://dx.doi.org/10.17306/J.NPT.00197

Although the fewest species were recorded in urbanised habitats, they can be as rich in parasitoids as rural areas, if not richer in biodiversity. Midfield thickets, which make so-called ecological corridors in the agricultural environment, are very similar to urban habitats in terms of guilds of parasitoids of aphids of the Aphis genus. The faunas of parasitoids from both types of habitats were mixed. This fact shows that populations of parasitoids penetrated urbanised environments by migrating from agrocenoses, midfield thickets and from other semi-natural habitats in the agricultural environment, e.g. from meadows and forests, and vice versa. It seems that parasitoids of aphids are undergoing the process of synurbisation (Barczak et al., 1999).

The comparison of the environments revealed big differences in species composition as well as the number of species. Many species were extremely common in the agricultural environment, forests and urban areas. They were found in most of the areas and in all the environments under study. The Aphidius genus was represented by numerous species, such as: Aphidius ervi, A. matricariae, A. picipes, A. salicis, A. setiger and A. sonchi. The Diaeretiella, Ephedrus, Lysiphlebus, Praon, Trioxys genera also had their representatives, i.e. Diaeretiella rapae, Ephedrus persicae, E. plagiator, Lysiphlebus ambiguous, L. fabarum, Praon abjectum, P. volucre, Trioxys acalephae and T. angelicae. It is noteworthy that Praon volucre had a wide range of hosts. It was chiefly found on the edge of forests, but it also parasitised aphids in farmlands and orchards. Trioxys angelicae is a very useful species for biological methods. It is a polyphagous species found in forests, parks, and farmlands. It parasitised many aphid species, especially of the Aphis genus. Lysiphlebus fabarum could be found in each environment. It often parasitised aphids belonging to the Aphis spp. and Brachycaudus spp. (Ślusarczyk, 1994). On the other hand, some species occurred only in certain environments. The following species were found only in the agricultural environment: Aphidius transcaspicus, Ephedrus palaestinensis, Lipolexis gracilis, Lysephedrus validus, and Toxares deltiger. Aclitus obscuripennis, Aphidius hieraciorum, Areopraon lepelleyi, Diaeretus leucopterus, Pauesia abietis, P. cupressobi, and P. infulata were found only in forests, whereas Aphidius caraganae, and Monoctonus cerasi were observed in urban areas. These species were shown in certain environments only because of the narrow range of hosts or due to the lack of research data.

\section{Conclusion}

Forests were the most abundant in Braconid parasitic wasps in Poland. They were followed by agricultural environments and urban areas. Populations of parasitoids are likely to infiltrate urbanised environments by moving from agrocenoses, fields and from other semi-natural habitats in the agricultural landscape, e.g. from grasslands, forests and back. 
Tran Dinh, D., Piekarska-Boniecka, H., Rzańska-Wieczorek, M. (2017). Aphidiinae (Hymenoptera, Braconidae) occurring in agricultural environments, forests and urban areas in Poland. Nauka Przyr. Technol., 11, 3, $305-313$. http://dx.doi.org/10.17306/J.NPT.00197

\section{References}

Atanassova, P. V. (1997). Checklist of the subfamily Aphidiinae (Hymenoptera: Braconidae) from Bulgaria. Zool. Meded. (Leiden), 71, 24, 287-290. http://www.repository.naturalis.nl/ record $/ 319220$

Barczak, T. (1988). Owady - naturalni wrogowie mszycy trzmielinowo-burakowej, Aphis fabae Scop. (Homoptera, Aphididae). Wiad. Entomol., 8, 1-2, 13-26.

Barczak, T. (1991-1992a). Parazytoidy kompleksu mszycy burakowej - Aphis fabae (Homoptera, Aphididae) w Polsce. I. Zgrupowania parazytoidów na trzmielinie europejskiej - Euonymus europaeus L. Pol. Pismo Entomol., 61, 1, 97-106.

Barczak, T. (1991-1992b). Parazytoidy kompleksu mszycy burakowej - Aphis fabae (Homoptera, Aphididae) w Polsce. II. Zgrupowanie parazytoidów na buraku - Beta vulgaris L. Pol. Pismo Entomol., 61, 1, 107-115.

Barczak, T. (1994). Naturalni wrogowie mszyc i ich znaczenie w ochronie roślin. Wiad. Entomol., 13, 3, 141-152.

Barczak, T., Bennewicz, J., Kaczorowski, G., Dębek-Jankowska, A. (1999). Pasożytnicze błonkówki (Hymenoptera - Parasitica) stowarzyszone z mszycami - Aphidodea (Homoptera) w zaroślach śródpolnych. Wiad. Entomol., 18, 1, 33-39.

Barczak, T., Bennewicz, J., Kaminski, P. (2013). Parasitoids (Hymenoptera: Braconidae, Aphidiinae) of the mealy plum aphid Hyalopterus pruni (Geoffr.) on common reed (Phragmites australis) in different types of habitat in Poland. Arch. Biol. Sci. (Belgr.), 65, 1, 71-79. http://dx.doi.org/10.2298/ABS1301071B

Barczak, T., Dębek-Jankowska, A., Bennewicz, J. (2005). Parasitic entomofauna in urban and agricultural landscapes of the Pomorze and Kujawy region. I. Primary parasitoids of aphids from the Aphis genera. Folia Biol. (Cracow), 53, Suppl., 157-164. http://www.isez.pan. krakow.pl/en/folia-biologica.html

Barczak, T., Dębek-Jankowska, A., Bennewicz, J. (2014). Primary parasitoid and hyperparasitoid guilds (Hymenoptera) of grain aphid (Sitobion avenae F.) in northern Poland. Arch. Biol. Sci. (Belgr.), 66, 3, 1141-1148. http://dx.doi.org/10.2298/ABS1403141B

Belokobylskij, S. A., Taeger, A., van Achterberg, C., Haeselbarth, E., Riedel, M. (2003). Checklist of the Braconidae of Germany (Hymenoptera). Beitr. Entomol., 53, 2, 341-435. https://dx. doi.org/10.21248/contrib.entomol.53.2.341-435

Cierniewska, B. (1973). Parasites of aphids occurring in the orchards near Poznan (Hymenoptera, Aphidiidae). Pol. Pismo Entomol., 43, 4, 837-839.

Fauna Europaea. All European animal species online. Berlin: Museum für Naturkunde. http://www.faunaeur.org (accessed 2 October 2015).

Goszczyński, W., Tykarska, K., Szybczyński, K. (2000). Aphids and their natural enemies on whitehorn (Crataegus oxyacantha L.) in the parks of Warsaw. In: E. Cichocka, M. Ruszkowska, W. Goszczyński, D. Ciepielewska (eds.), Aphids and other homopterous insects, vol. 7 (pp. 261-266). Olsztyn: University of Warmia and Masuria.

Halarewicz-Pacan, A., Sobota, G. (1998). Parasitic Hymenoptera associated with aphids on biologically protected plants in glasshouses of the Botanical Garden in Wrocław. In: E. Cichocka, W. Goszczyński, K. Wiech (eds.), Aphids and other homopterous insects, vol. 6 (pp. 107-110). Warsaw: Warsaw Agricultural University.

Jaśkiewicz, B. (2003). The occurrence of aphids and their natural enemies on juniper shrubs in the area of Lublin. Electr. J. Pol. Agric. Univ. Ser. Hortic., 6, 1, \#04. http://www.ejpau.media.pl/ volume6/issue1/horticulture/art-04.html

Kierych, E. (1975). Materiały do znajomości Aphidiidae (Hymenoptera) Polski. Fragm. Faun. (Warsaw), 20, 15, 233-246. 
Tran Dinh, D., Piekarska-Boniecka, H., Rzańska-Wieczorek, M. (2017). Aphidiinae (Hymenoptera, Braconidae) occurring in agricultural environments, forests and urban areas in Poland. Nauka Przyr. Technol., 11, 3, 305-313. http://dx.doi.org/10.17306/J.NPT.00197

Krawczyk, A., Hurej, M., Sobota, G. (2006). Aphids and their natural enemies occurring on maize in Opole province. In: B. Wilkaniec (ed.), Monograph. Aphids and other hemipterous insects, vol. 12 (pp. 127-136). Poznań: Agricultural University of Poznań.

Lopes, Th., Libert, P.-N., Starý, P., Japoshvili, G., Hatt, S., Francis, F. (2016). Checklist of Aphidiinae (Hymenoptera: Braconidae) and Aphelinus (Hymenoptera: Aphelinidae) species from Belgium with respectively four and three new records. Zootaxa, 4092, 4, 548-560. http://dx.doi.org/10.11646/zootaxa.4092.4.5

Pankanin-Franczyk, M. (1982). Participation of parasitoids in limiting the numbers of aphids on cereal crops. Pol. Ecol. Stud., 8, 3-4, 521-538.

Pankanin-Franczyk, M. (1987). Occurrence of aphids and their parasitoids on rye crops differently surrounded. Pol. Ecol. Stud., 13, 2, 215-226.

Pankanin-Franczyk, M., Ceryngier, P. (1995). Cereal aphids, their parasitoids and coccinellids on oats in central Poland. J. Appl. Entomol., 119, 1-5, 107-111. http://dx.doi.org/10.1111/j.1439-0418.1995.tb01253.x

Pankanin-Franczyk, M., Sobota, G. (1998). Relationships between primary and secondary parasitoids of cereal aphids. J. Appl. Entomol., 122, 1-5, 389-395. http://dx.doi.org/10.1111/j.1439$-0418.1998 . t b 01517 . \mathrm{x}$

Sobota, G., Gabryś, B. (2000). Parasitoids and hyperparasitoids of aphids caught in yellow traps in selected field crops. In: E. Cichocka, M. Ruszkowska, W. Goszczyński, D. Ciepielewska (eds.), Aphids and other homopterous insects, vol. 7 (pp. 297-303). Olsztyn: University of Warmia and Masuria.

Sobota, G., Pankanin-Franczyk, M., Gabryś, B., Gadomski, H., Halarewicz-Pacan, A. (1998). The role of hyperparasitoids in limiting populations of Aphidiidae on field crops. In: E. Cichocka, W. Goszczyński, K. Wiech (eds.), Aphids and other homopterous insects, vol. 6 (pp. 111116). Warsaw: Warsaw Agricultural University.

Starý, P. (2006). Aphid parasitoids of the Czech Republic (Hymenoptera: Braconidae, Aphidiinae). Praha: Academia.

Ślusarczyk, J. (1994). Aphid parasites (Hymenoptera, Aphidiidae) found on the trees and herbaceous plants of the Kielce urban area. Rocz. Nauk Roln. Ser. E, 24, 1-2, 21-25.

Twardowski, J., Hurej, M. (2000). Parasitic Hymenoptera on strips of flowering plants. In: E. Cichocka, M. Ruszkowska, W. Goszczyński, D. Ciepielewska (eds.), Aphids and other homopterous insects, vol. 7 (pp. 313-318). Olsztyn: University of Warmia and Masuria.

Wiąckowski, S. K. (1997). Aphid parasitoids (Hymenoptera, Aphidiidae) appearing on the crop plants. Rocz. Nauk Roln. Ser. E, 26, 1-2, 35-40.

Wiąckowski, S. K., Wiąckowska, I. (1996). Pasożyty mszyc (Hymenoptera Aphididae) roślin sadowniczych. Zesz. Nauk. Inst. Sadown. Kwiac., 3, 115-118.

Wiąckowski, S. K., Wiąckowska, I. (2000). Parazytoidy mszyc (Hymenoptera: Aphidiidae) występujące na drzewach i krzewach leśnych. Wiad. Entomol., 19, 2, 93-103.

Wiąckowski, S. K., Wiąckowska, I., Mężyk, Z. (1997). Mszyce (Homoptera, Aphidodea) i ich pasożyty (Hymenoptera, Aphidiidae) występujące na roślinach ozdobnych. Zesz. Nauk. Inst. Sadown. Kwiac., 4, 191-195.

Wiąckowski, S. K., Wiąckowska, I., Werstak, K., Ślusarczyk, J. (2001). Parazytoidy mszyc (Hymenoptera: Aphidiidae) Polski centralnej i południowej. Wiad. Entomol., 20, 1-2, 57-65.

Yu, D. S. K., van Achterberg, C., Horstmann, K. (2012). Taxapad 2012. World Ichneumonoidea 2011. Database on flash-drive. Ottawa. http://www.taxapad.com 
Tran Dinh, D., Piekarska-Boniecka, H., Rzańska-Wieczorek, M. (2017). Aphidiinae (Hymenoptera, Braconidae) occurring in agricultural environments, forests and urban areas in Poland. Nauka Przyr. Technol., 11, 3, 305-313. http://dx.doi.org/10.17306/J.NPT.00197

\title{
APHIDIINAE (HYMENOPTERA, BRACONIDAE) WYSTĘPUJĄCE W ŚRODOWISKU ROLNICZYM I LEŚNYM ORAZ W ZIELENI MIEJSKIEJ NA TERENIE POLSKI
}

\begin{abstract}
Abstrakt
W artykule przedstawiono na podstawie danych literaturowych zróżnicowanie gatunkowe parazytoidów z podrodziny Aphidiinae (Braconidae) stwierdzonych w uprawach rolniczych, w lasach i w zieleni miejskiej na terenie Polski. Łącznie we wszystkich środowiskach stwierdzono 83 gatunki parazytoidów. Lasy były środowiskiem najbardziej preferowanym przez Aphidiinae: wykazano w nich 61 gatunków tych parazytoidów. W środowisku rolniczym stwierdzono 41 gatunków, a w zieleni miejskiej 38. Wszystkie środowiska zasiedlało 15 następujących gatunków: Aphidius ervi, A. matricariae, A. picipes, A. salicis, A. setiger, A. sonchi, Diaeretiella rapae, Ephedrus persicae, E. plagiator, Lysiphlebus ambiguous, L. fabarum, Praon abjectum, P. volucre, Trioxys acalephae i T. angelicae.
\end{abstract}

Słowa kluczowe: Aphidiinae, parazytoid, środowisko rolnicze i leśne, zieleń miejska

Corresponding address - Adres do korespondencji:

Duong Tran Dinh, Katedra Entomologii i Ochrony Środowiska, Uniwersytet Przyrodniczy w Poznaniu, ul. Dąbrowskiego 159, 60-594 Poznań, Poland, e-mail: tdduong@iebr.ac.vn, boniecka@up.poznan.pl

Accepted for publication - Zaakceptowano do opublikowania:

5.09.2017

For citation - Do cytowania:

Tran Dinh, D., Piekarska-Boniecka, H., Rzańska-Wieczorek, M. (2017). Aphidiinae (Hymenoptera, Braconidae) occurring in agricultural environments, forests and urban areas in Poland. Nauka Przyr. Technol., 11, 3, 305-313. http://dx.doi.org/10.17306/J.NPT.00197 